\title{
MORPHO-PHYSIOLOGICAL RESPONSES OF SUNFLOWER TO FOLIAR APPLICATIONS OF CHLORMEQUAT CHLORIDE (CCC)
}

\author{
RESPOSTAS MORFO-FISIOLÓGICAS DE GIRASSOL PARA APLICACÕES \\ FOLIARES DE CHLORMEQUAT CHLORIDE (CCC)
}

\author{
Spyridon D. KOUTROUBAS ${ }^{1}$; Christos A. DAMALAS ${ }^{2}$ \\ 1. Professor, Department of Agricultural Development, Democritus University of Thrace, Orestiada, Greece, skoutrou@ agro.duth.gr; 2. \\ Assistant Professor, Department of Agricultural Development, Democritus University of Thrace, Orestiada, Greece, \\ chris.damalas@yahoo.gr; cdamalas@agro.duth.gr
}

\begin{abstract}
Chlormequat chloride (CCC) is used to inhibit extension growth in cereals and promote branching and flowering in potted ornamental plants produced in greenhouses; however, experimental data on the use of CCC in field sunflower are limited. Field experiments were conducted to study the effect of foliar applications of CCC at rates of 3,000 $\mathrm{g} \mathrm{ha}^{-1}$ (single application) and 3,000 plus 3,000 $\mathrm{g} \mathrm{ha}^{-1}$ (double application) on the morphology and productivity of sunflower plants. CCC provoked some foliar injury on sunflower plants within a week after application, but the effect was transient; the symptoms were reduced over time and the plants recovered completely. Single application of CCC did not provide significant height reduction of sunflower plants as opposed to double application, which reduced plant height at maturity by $12.7 \%$ (or by $43.4 \mathrm{~cm}$ ). Both application schemes promoted flowering and induced the production of more achenes, but finally resulted in reduced achene yield per plant by $17.8 \%$ and $20.3 \%$, respectively, compared with the non-treated control. The achene yield reduction resulted by the reduction in the 100 -achene weight. The study provides new evidence that allow a better understanding of the mode of action of CCC in sunflower. Overall, the foliar applications of CCC at the rates tested in this study either did not provide any advantage in terms of height reduction of sunflower plants or the height reduction achieved was accompanied by significant reduction in achene yield. On the basis of all the above, CCC does not appear to be a suitable growth regulator for the control of plant height in sunflower.
\end{abstract}

KEYWORDS: 100-achene weight. Achene yield. Foliar applications. Growth regulator.

\section{INTRODUCTION}

Phytohormones play an important role in plant growth by affecting many physiological activities (GRAY, 2004). Various synthetic growth regulators, which include both promoters as well as inhibitors, are known for increasing the yield of several field crops. In addition, growth regulators are used to reduce the internodal length, in an effort to control plant height (GROSSMANN, 1990). These chemical substances also influence the source-sink relationship and stimulate the translocation of photoassimilates towards developing reproductive parts (i.e., sink). Growth retardants may also enhance the chlorophyll content of leaves, which helps to increase the functional life of the source, thus leading to improved partitioning efficiency and increased productivity. Reduced plant height and increased functional life of the source, especially during the grain filling stage in sunflower, are essential for improving productivity.

Chlormequat chloride (CCC), the first plant growth retardant, was discovered in the late 1950s; applications on wheat produced shorter plants with thicker stems (TOLBERT, 1960). It belongs to the onium-type compounds, which possess a quaternary ammonium, i.e., a positively charged ammonium
(RADEMACHER, 2000). Chlormequat chloride is an anti-gibberellin compound that blocks the early stages of gibberellin synthesis and limits stem elongation in plants, thereby creating shorter plants that are more resistant to lodging (GIANFAGNA, 1995). Inhibiting products of gibberellin are used commercially to prevent lodging in some plants. Nowadays, CCC is used to inhibit extension growth in cereals and to promote flowering or control growth of floricultural crops grown in greenhouses. Growth inhibition responses of sprays typically last only for a few weeks, so multiple applications may be necessary. However, the product to be used as well as the dose and application times varies with the crop and the cultivar.

The effect of foliar applications of $\mathrm{CCC}$ has been well documented in several earlier studies for cereals (GREEN, 1986; NAYLOR, 1989; EMAM; KARIMI, 1996; RAJALA; PELTONEN-SAINIO, 2001; STACHECKI et al., 2004; TOYOTA et al., 2009). In addition, the morphological effects of applying CCC to a number of other crops are also documented (PRASAD; SHUKLA, 1991; GIRIDHAR; GIRI, 1997; PASSAM et al., 2008; GHOLAMPOUR et al., 2015). However, data for the effect of CCC on growth of field sunflower is highly limited. Lovett and Campbell (1973) reported 
that soil drench application of CCC at the two-leaf stage reduced plant height of sunflower through reduction in the internode length. Single foliar application of CCC at $1,500 \mathrm{~g} \mathrm{ha}^{-1}$ was not effective in reducing sunflower plant height (KOUTROUBAS et al., 2014). On the other hand, double foliar application of CCC at 1,500 + 1,500 g $\mathrm{ha}^{-1}$ reduced sunflower plant height by $13.4 \%$ compared with the non-treated control, but this treatment proved in certain cases to have a phytotoxic effect on sunflower plants in terms of achene and oil production (KOUTROUBAS et al., 2014). Differences between studies are not surprising, considering the inconsistent performance of many plant growth regulators and the diverse effects on plant growth related to the timing of application (i.e., the growth stage of crop), the application dose, as well as the variable effects of the environmental conditions at application (STOVER; GREENE, 2005).

The available data concerning CCC use in field sunflower showed variable response at the doses used, therefore, suggesting further investigation. Control of sunflower plant height is of great practical importance because it can provide increased resistance to lodging, particularly under adverse growth conditions, and also facilitate mechanical harvest (FICK; MILLER, 1997). Considering the ineffectiveness of CCC in reducing sunflower plant height at $1,500 \mathrm{~g} \mathrm{ha}^{-1}$ in a previous study, the purpose of this study was to evaluated the effects of foliar applications of CCC at 3,000 g $\mathrm{ha}^{-1}$ and $3,000+3,000 \mathrm{~g} \mathrm{ha}^{-1}$ on sunflower morphology and productivity under field conditions.

\section{MATERIAL AND METHODS}

The effects of foliar applications of CCC were evaluated in two field experiments with a local population (i.e., traditional landrace) of non-oilseed sunflower carried out in $2003\left(1^{\text {st }}\right.$ growing season, GS) and 2004 ( $2^{\text {nd }}$ growing season, GS) in Orestiada $\left(41^{\circ} 33^{\prime} \mathrm{N}\right.$ latitude, $26^{\circ} 31^{\prime} \mathrm{E}$ longitude, $33 \mathrm{~m}$ a.s.l) in northern Greece. The experiments were established on a clay loam soil $(28.7 \%$ clay, $46.1 \%$ silt, and $25.2 \%$ sand) with $\mathrm{pH}\left(1: 1\right.$ with $\left.\mathrm{H}_{2} \mathrm{O}\right) 6.6$, organic matter content $2.4 \%$, CEC $27.7 \mathrm{meq} 100 \mathrm{~g}^{-1}, \mathrm{~N}^{-\mathrm{NH}_{4}}$ $9.3 \mathrm{ppm}, \mathrm{P}$ (Olsen) $46.9 \mathrm{ppm}$, and K $457.6 \mathrm{ppm}(0$ to $30 \mathrm{~cm}$ depth). The preceding crop in the experimental area was sugar beet (Beta vulgaris L.).

Seedbed preparation was done in mid spring of each year soil with conventional tillage operations, chisel ploughing and harrowing twice. Sunflower was planted in rows spaced $75 \mathrm{~cm}$ apart on May 32003 and April 25 2004. Plants on the row were spaced $30 \mathrm{~cm}$ apart and a seeding rate of $7 \mathrm{~kg}$ $\mathrm{ha}^{-1}$ was used. Planting patterns yielded a crop density of 44,400 plants $\mathrm{ha}^{-1}$ following the usual practice of farmers in the area. Plots consisted of 4 rows of the crop, 8-m long each. Nitrogen $(\mathrm{N})$ at 50 $\mathrm{kg} \mathrm{ha}{ }^{-1}$ in the form of ammonium sulphate, phosphorus pentoxide $\left(\mathrm{P}_{2} \mathrm{O}_{5}\right)$ at $50 \mathrm{~kg} \mathrm{ha}^{-1}$ in the form of superphosphate, and potassium oxide $\left(\mathrm{K}_{2} \mathrm{O}\right)$ at $50 \mathrm{~kg} \mathrm{ha}^{-1}$ in the form of potassium sulfate were broadcast applied and incorporated into the soil before sowing. The crop was irrigated twice; once at the early growth stages of the crop and once before flowering. Weeds were controlled manually during the early crop growth.

In the $1^{\text {st }} \mathrm{GS}, \mathrm{CCC}$ was applied at the rate of 3,000 $\mathrm{g} \mathrm{ha}^{-1} 33$ days after sowing, when plants had five to six true leaves (BBCH 15-16) (MEIER, 2001). A non-treated control was included for comparison. Because of no considerable response of sunflower plants in terms of height reduction was recorded in the $1^{\text {st }} \mathrm{GS}$, an extra application was made for CCC in the $2^{\text {nd }}$ GS to better clarify the proper application scheme. Thus, in the $2^{\text {nd }} \mathrm{GS}$, CCC was applied twice at 3,000 +3,000 $\mathrm{g} \mathrm{ha}^{-1}$. In this case, the first application took place 26 days after sowing, at the four to five true leaves $(\mathrm{BBCH}$ 14-15) of sunflower plants, while the second application took place two weeks after the first one, i.e. at the five to six true leaves. The treatments were arranged in a randomized complete block design with four replications. CCC treatments were applied with a portable hand-held field plot sprayer at $250 \mathrm{kPa}$ pressure using a water carrier volume of $500 \mathrm{~L} \mathrm{ha}^{-1}$.

Visual rating of sunflower injury was based on a scale of 0 (no injury) to $100 \%$ (plant death) 7 days after treatment. In addition, plant height, number of stem nodes, and stem diameter were measured at maturity using 10 plants from each plot labelled 2 days prior to the application of CCC. Plant height was measured from the soil surface to the top of the uppermost plant organ. Measurements of stem diameter were taken from the second internode of the plants. Three plants by each plot were sampled at flowering and maturity. The aboveground biomass of the plants were harvested and separated into leaves, stems, and capitula. At maturity, capitula were partitioned into vegetative parts and achenes. Achenes were separated by hand in filled and unfilled ones and the number of each group was determined. All plant samples were ovendried at $70^{\circ} \mathrm{C}$ to constant weight and weighted. Achene yield (expressed as $\mathrm{g}$ plant $^{-1}$ ) was determined on the basis of the filled achenes. In addition, the percentage of achene oil was 
determined with the Soxhlet extraction method according to the official methods of the American Oil Chemists' Society (AOCS, 1983).

All measured and derived data were subjected to analysis of variance (ANOVA) using one-way ANOVA with two treatments (the CCC treatment plus the non-treated control) and four replications according to Steel and Torrie (1980). Because there was an extra application for CCC in the $2^{\text {nd }} \mathrm{GS}$, the data were analyzed separately for each year. Differences between means for each variable were compared with the least significant difference (LSD) at 5\% level of significance.

\section{RESULTS AND DISCUSSION}

Temperature variation in each cropping period of the experimentation is given in Table 1 . Mean temperature was $20.8^{\circ} \mathrm{C}$ in the $1^{\text {st }} \mathrm{GS}$ and $20.2^{\circ} \mathrm{C}$ in the $2^{\text {nd }} \mathrm{GS}$. Also, total seasonal rainfall was similar in the two years $\left(188.3 \mathrm{~mm}\right.$ in the $1^{\text {st }} \mathrm{GS}$ and $180.1 \mathrm{~mm}$ in the $2^{\text {nd }} \mathrm{GS}$ ), although differences in rainfall distribution were recorded between seasons. However, these differences were normalized by the artificial irrigation applied and, therefore, were not crucial for sunflower growth and development. In both years, a slight amount of foliar injury was observed on sunflower leaves within 7 days after treatment, but the effect was transient and the plants recovered after a week from application.

Table 1. Mean monthly air temperature and cumulative rainfall by month during the experimentation.

\begin{tabular}{|c|c|c|}
\hline Month & Mean temperature & Total rainfall \\
\hline & \multicolumn{2}{|c|}{$1^{\text {st }}$ growing season } \\
\hline April & 9.8 & 63.1 \\
\hline May & 19.7 & 70.9 \\
\hline June & 24.3 & 0.6 \\
\hline July & 25.7 & 38.5 \\
\hline August & 26.5 & 0.8 \\
\hline September & 18.8 & 14.4 \\
\hline & \multicolumn{2}{|c|}{$2^{\text {nd }}$ growing season } \\
\hline April & 12.5 & 7.3 \\
\hline May & 16.6 & 64.6 \\
\hline June & 22.1 & 73.5 \\
\hline July & 24.1 & 24.7 \\
\hline August & 24.9 & 10.0 \\
\hline September & 21.1 & 0.0 \\
\hline
\end{tabular}

Plant height was not affected significantly by the single application of CCC in the $1^{\text {st }} \mathrm{GS}$, but a significant reduction of plant height by $12.7 \%$ (or by $43.4 \mathrm{~cm}$ ) compared with the non-treated control was observed with the double application of CCC in the $2^{\text {nd }}$ GS (Figure 1A). The reduction in plant height was accompanied by a reduction in the number of stem nodes per plant (Figure 1B). Regarding stem diameter, there was a trend for thicker stems of sunflower plants treated with CCC (single or double application), but the differences with the non-treated control were not significant in any GS (Figure 1C).

In both GS, there was significantly higher above ground dry weight of sunflower plants treated with CCC than the non-treated control at flowering (Figure 2A). However, this trend was not maintained until maturity, where no significant differences were detected (Figure 2B).
In both GS, CCC treatments resulted in significantly lower achene yield per plant compared with the non-treated control (Figure 3A). This reduction was $17.8 \%$ with the single application of $\operatorname{CCC}\left(1^{\text {st }} \mathrm{GS}\right)$ and $20.3 \%$ with the double application of CCC ( $2^{\text {nd }}$ GS $)$. Similarly, CCC treatments resulted in reduced 100-achene weight (based on filled achenes) by $13.9 \%$ in the $1^{\text {st }}$ GS and by $16.8 \%$ in the $2^{\text {nd }}$ GS (Figure 3B). However, the total number of achenes in plants treated with CCC increased in both years (Figure 3C).

Regarding the number of filled achenes, there was an increasing trend with application of $\mathrm{CCC}$, particularly in the $2^{\text {nd }} \mathrm{GS}$, but the differences were not significant in any year (Figure 3D). None of the CCC treatments affected achene $\mathrm{N}$ or achene oil content (Figure 4A, B). 

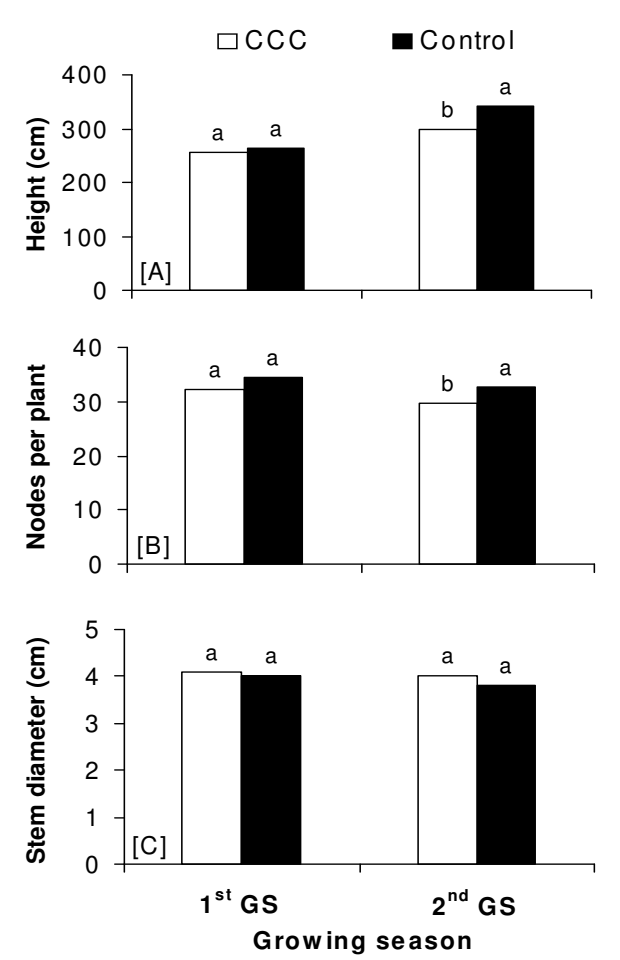

Figure 1. (A) Plant height, (B) number of nodes, and (C) stem diameter of sunflower plants at maturity as influenced by foliar applications of CCC $\left(3,000 \mathrm{~g} \mathrm{ha}^{-1}\right.$ in the $1^{\text {st }}$ growing season, GS and 3,000+ $3,000 \mathrm{~g} \mathrm{ha}^{-1}$ in the $2^{\text {nd }}$ growing season, GS). Columns within GS with the same letter indicate values that were not significantly different at $P<0.05$.

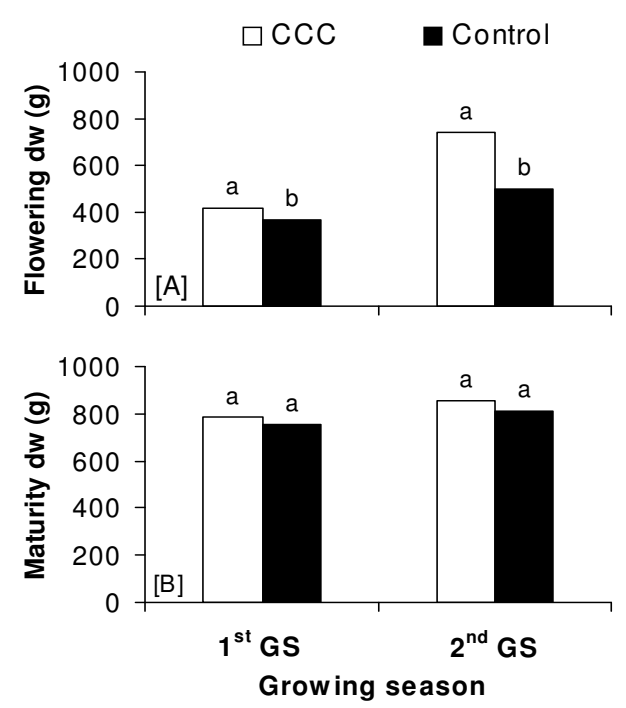

Figure 2. Above ground dry weight of sunflower plants at (A) flowering and (B) maturity as influenced by foliar applications of CCC $\left(3,000 \mathrm{~g} \mathrm{ha}^{-1}\right.$ in the $1^{\text {st }}$ growing season, GS and 3,000 +3,000 $\mathrm{g} \mathrm{ha}^{-1}$ in the $2^{\text {nd }}$ growing season, GS). Columns within GS with the same letter indicate values that were not significantly different at $P<0.05$. 

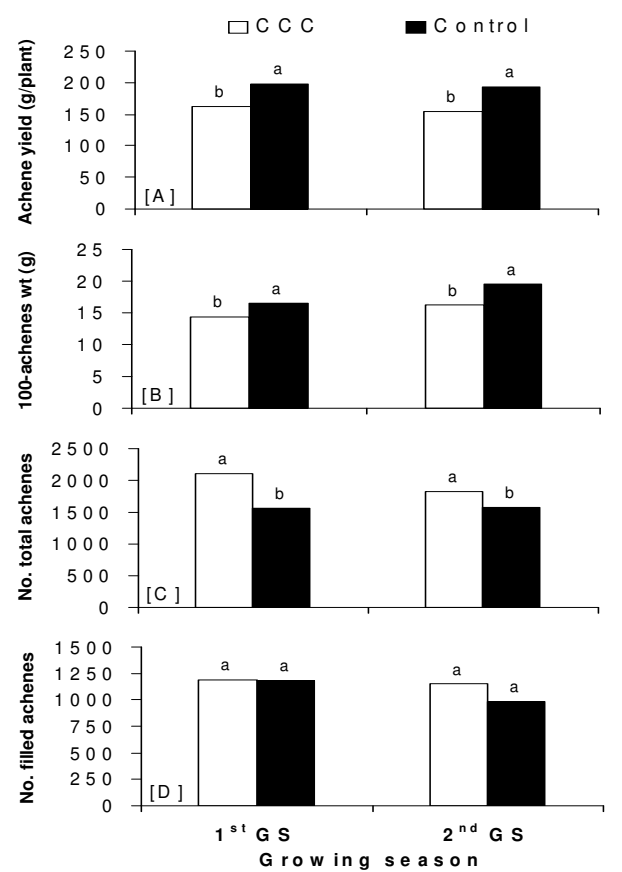

Figure 3. (A) Achene yield, (B) 100-achenes weight (filled), (C) total achenes per capitulum and (D) filled achenes per capitulum of sunflower plants as influenced by foliar treatments of CCC $\left(3,000 \mathrm{~g} \mathrm{ha}^{-1}\right.$ in the $1^{\text {st }}$ growing season, GS and 3,000 $+3,000 \mathrm{~g} \mathrm{ha}^{-1}$ in the $2^{\text {nd }}$ growing season, GS). Columns within GS with the same letter indicate values that were not significantly different at $P<0.05$.

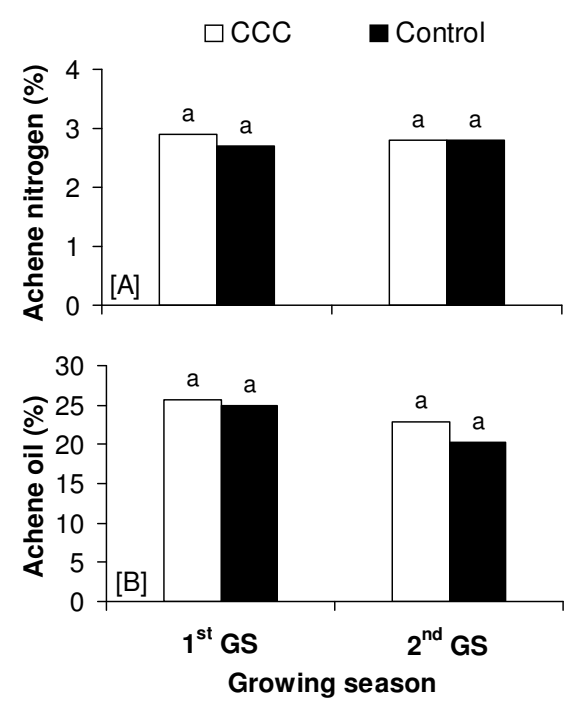

Figure 4. (A) Achene nitrogen content and (B) achene oil content of sunflower plants as influenced by foliar treatments of CCC $\left(3,000 \mathrm{~g} \mathrm{ha}^{-1}\right.$ in the $1^{\text {st }}$ growing season, GS and 3,000 $+3,000 \mathrm{~g} \mathrm{ha}^{-1}$ in the $2^{\text {nd }}$ growing season, GS). Columns within GS with the same letter indicate values that were not significantly different at $P<0.05$.

This study provides new evidence on the possibility of using CCC to control plant height in sunflower under field conditions. The single application of CCC at the rate tested in the present study failed to reduce the height of sunflower plants and, additionally, it had a detrimental effect on achene yield. On the other hand, the double application of CCC provided a significant reduction of plant height at maturity by $12.7 \%$ (or by 43.4 $\mathrm{cm}$ ), but it also reduced significantly the achene yield. The decrease of achene yield observed with both CCC treatments was associated with a significant reduction of 100 -achene weight. Seed weight in sunflower is considered an important yield attributing character that has been reported to have the highest direct positive effect on seed yield per 
sunflower plant (MARINKOVIC, 1992) along with the number of seeds per head and the head diameter (YASIN; SINGH, 2010). In addition, individual seed weight is of paramount importance in nonoilseed (confection) sunflower because it is associated with seed size, a trait that is often used in grading seeds, with the largest ones being preferred by customers. Thus, the detrimental effect of CCC on achene weight is a severe limiting factor for this type of sunflower.

Previous research with sunflower showed that soil drench application of CCC at the rate of $4,000 \mathrm{ppm}$ resulted in decreased plant height through a reduction in the internode length, without mentioning a reduction in achene yield (LOVETT; CAMPBELL, 1973). In the same study, increased stem width, head diameter, and photosynthetic area were amongst the responses to CCC. In another study, single foliar application of CCC at the rate of $1,500 \mathrm{ppm}$ did not provide a significant plant height control in sunflower, whereas the double foliar application of CCC at 1,500+1,500 ppm resulted in a significant plant height reduction (KOUTROUBAS et al., 2014). However, this reduction in sunflower plant height was accompanied by lower achene yield, indicating a clear phytotoxic response of sunflower plants compared with the non-treated control. A similar response was also evident in the present study, where both CCC application schemes (i.e., single or double foliar application) reduced the achene yield per plant by $17.8 \%$ and $20.3 \%$, respectively. These results do not encourage the use of CCC for controlling sunflower plant height due to the accompanied detrimental effect on achene yield and achene weight. However, the application of CCC could be considered as a means for reducing plant height of field sunflower only where severe losses in achene yield due to plant lodging and mechanical harvesting is a common phenomenon. Usually, this is the case of unimproved traditional sunflower landraces, which usually exhibit tall plants or plants that exceed in height those caused by the foliar application of CCC in the present study, particularly when adverse environmental conditions prevail. In addition, CCC application at an earlier stage of sunflower could be more effective in reducing plant height without causing any detrimental effects on yield, but this issue requires further investigation.

Some foliar injury (marginal leaf yellowing) was observed on sunflower leaves by the CCC treatments in the present study, but the effect was temporary and the plants fully recovered after a week from application. Similarly, Spitzer et al. (2011) observed some extent of foliar injury with
CCC on sunflower. Foliar sprays of CCC have been reported to cause injury in ornamental plants in the form of yellow spotting, haloing, or discoloration of newly developing leaves (LOPEZ; CURREY, 2010). Phytotoxicity problems with applications of CCC usually occur when the concentration of the sprays exceeds $1,500 \mathrm{ppm}$ and symptoms are usually visible within 3 to 5 days after spraying as a result of damage to the chloroplasts; leaves usually recover rapidly, depending on the sensitivity of cultivars and species (LOPEZ; CURREY, 2010). Late applications of CCC can induce phytotoxicity and therefore application of $\mathrm{CCC}$ at an earlier stage of sunflower, as noted above, probably would have prevented foliar injury; however, this issue requires further investigation.

The results of this study generally agree with those previously reported in the literature on the effect of CCC on sunflower or on other crops. The shortening effect of CCC on sunflower plants appeared to be associated with the application scheme. Single application of CCC reduced plant height mostly due to a reduction of the internode length, because the number of stem nodes was not affected significantly. On the other hand, the shortening effect of double application of CCC was due to the reduction of the number of stem nodes per plant. These results are in agreement with Weiss (2000), who reported that certain growth regulators generally reduced height of sunflower plants at maturity by affecting the internode length, although a different reaction to the chemical used or to the rate applied may exist depending on cultivar.

The application of CCC increased the total number of achenes, but the number of filled achenes did not differ significantly between the CCC-treated plants and the non-treated control. This means that CCC promoted flowering and induced production of more achenes, but this increase did not result in higher achene yield than the non-treated-control. Practically, CCC increased the number of empty achenes and reduced the weight of filled achenes compared with the non-treated control. It seems that CCC application enhanced yield potential of sunflower plant through improving of sink (i.e., higher total number of achenes/head), but this yield potential was not realized as indicated by the poor filling of achenes. This was observed despite the fact that the supply of assimilates (i.e., source strength) was greater in plants treated with CCC, as suggested by the higher dry matter accumulation obtained at flowering compared with the non-treated control plants. These results suggest that there might have been a limitation in the transport system of assimilates from source to sink due to the 
Morpho-physiological responses of sunflower...

application of CCC. However, more research is needed to document this explanation. The results of the present study are in agreement with those of Naylor (1989), who reported that application of CCC in triticale consistently increased the number of grains per ear, but this was compensated to some extent by a lower mean grain weight. On the contrary, other studies have shown that CCC promotes seed yield probably due to redirection of assimilates which would normally have been utilized in vegetative growth, towards reproductive development. Spraying with CCC at the rosette stage of mustard (Brassica juncea) increased seed yield and seed protein content of mustard (PRASAD; SHUKLA, 1991). Also, application of $500 \mathrm{ppm} \mathrm{CCC}$ at the onset of bolting in lettuce increased seed yield in the autumn sown crop lettuce (PASSAM et al., 2008).

\section{CONCLUSIONS}

The study provides new evidence that allow a better understanding of the mode of action of CCC in field sunflower.
KOUTROUBAS, S. D.; DAMALAS, C. A.

The foliar applications of $\mathrm{CCC}$ at the rates tested in this study either did not provide any advantage in terms of height reduction of sunflower plants or the height reduction achieved was accompanied by significant reduction in achene yield. On the basis of all the above, CCC does not appear to be a suitable growth regulator for the control of plant height in sunflower.

The application of CCC could be considered as a means for controlling plant height in field sunflower only where achene losses are usually inevitable and these losses exceed those arising from the use of CCC. In addition, application of $\mathrm{CCC}$ at an earlier stage of sunflower probably could be more effective in reducing plant height, but the effect on yield should be also investigated. These issues along with testing other plant growth regulators might be main targets in further research studies for the control of plant height in sunflower.

RESUMO: Chlormequat chloride (CCC) é usado para inibir o crescimento em altura em cereais e promover a ramificação e floração em plantas ornamentais envasadas produzidas em estufas; no entanto, os dados experimentais sobre o uso de CCC em girassol são limitados. Os experimentos de campo foram conduzidos para estudar o efeito de aplicações foliares de CCC a taxas de $3.000 \mathrm{~g} \mathrm{ha}^{-1}$ (aplicação simples) e $3.000+3.000 \mathrm{~g} \mathrm{ha}^{-1}$ (aplicação dupla) sobre a morfologia e a produtividade das plantas de girassol. A aplicação de CCC provocou algum dano nas folhas de girassol em uma semana após a aplicação, mas o efeito foi transitório; os sintomas foram reduzidos ao longo do tempo e as plantas recuperaram completamente. Aplicação simples de CCC não propiciaram redução significativa da altura de plantas de girassol em oposição à dupla aplicação, que provocou redução da altura das plantas, na maturidade, de $12.7 \%$ (ou $43.4 \mathrm{~cm}$ ). Ambos os esquemas de aplicação promoveram floração e induziram a produção de mais aquênios, mas finalmente resultaram em redução do rendimento de aquênios por planta de $17.8 \%$ e $20.3 \%$, respectivamente, em comparação com o controle não tratado. A redução de rendimento de aquênios foi provocada pela redução do peso de 100 aquénios, porque o número de aquénios enchidos não foi afectado significativamente. $\mathrm{O}$ estudo fornece novas evidências de que permitem uma melhor compreensão do modo de ação do CCC em girassol. No geral, as aplicações foliares de CCC nas taxas testadas neste estudo, ou não fornecem qualquer vantagem em termos de redução da altura de plantas de girassol, ou a redução da altura alcançada foi acompanhada de redução significativa no rendimento de aquênios. Com base no que precede, CCC não parece ser um regulador de crescimento adequado para o controle da altura das plantas em girassol.

PALAVRAS-CHAVE: Peso de 100 aquênios. Rendimento de aquênios. Aplicações foliares. Regulador de crescimento.

\section{REFERENCES}

AOCS. Official and tentative methods of the American Oil Chemists' Society, $3^{\text {rd }}$ ed. Champaign, IL, USA: American Oil Chemists' Society; 1983.

EMAM, Y.; KARIMI, H. R. Influence of chlormequat chloride on five winter barley cultivars. Iranian Agricultural Research, v. 15, p. 101-114, 1996. 
FICK, G. N.; MILLER, J. F. Sunflower breeding. In: SCHNEITER, A. A. (Ed.). Sunflower Technology and Production, Monograph No. 35. Madison, WI, USA: ASA, CSSA, SSSA; 1997, p. 395-439.

GHOLAMPOUR, A.; HASHEMABADI, D.; SEDSGHATHOOR, S.; KAVIANI, B. Effect of chlormequat (cycocel) on the growth of ornamental cabbage and kale (Brassica oleracea) cultivars 'Kamome White' and 'Nagoya Red'. Journal of Environmental Biology, v. 36, p. 273-277, 2015.

GIANFAGNA, T. Natural and synthetic growth regulators and their use in horticultural and agronomic crops. In: DAVIES, P. (Ed.). Plant hormones: Physiology, biochemistry and molecular biology, 2nd ed. Dordrecht, Netherlands: Kluwer Academic Publishers; 1995, p. 751-774. http://dx.doi.org/10.1007/978-94011-0473-9_34

GIRIDHAR, K.; GIRI, G. Influence of chlormequat chloride (CCC) and phosphorus on growth and yield of groundnut (Arachis hypogaea) during the summer season in North West India. Journal of Agricultural Science, v. 129, p. 303-306, 1997. http://dx.doi.org/10.1017/S002185969700467X

GRAY, W. M. Hormonal regulation of plant growth and development. PLoS Biology v. 2, p. e311, 2004. http://dx.doi.org/10.1371/journal.pbio.0020311

GREEN, C. F. Modifications to the growth and development of cereals using chlorocholine chloride in the absence of lodging: a synopsis. Field Crops Research, v. 14, p. 117-133, 1986.

http://dx.doi.org/10.1016/0378-4290(86)90051-1

GROSSMANN, K. Plant growth retardants as tools in physiological research. Physiologia Plantarum, v. 78, p. 640-648, 1990. http://dx.doi.org/10.1111/j.1399-3054.1990.tb05254.x

KOUTROUBAS, S. D.; VASSILIOU, G., DAMALAS, C. A. Sunflower morphology and yield as affected by foliar applications of plant growth regulators. International Journal of Plant Production v. 8, p. 215-229, 2014.

LOPEZ, R. G.; CURREY, C. J. Chlormequat chloride (Cycocel or Citadel) phytotoxicity symptoms. Purdue Plant and Pest Diagnostic Laboratory. West Lafayette, IN, USA: Purdue Extension, 2010; Available at http://www.ppdl.purdue.edu/ppdl/weeklypics/3-29-10.html. Accessed 16 January 2016.

LOVETT, J. V.; CAMPBELL, D. A. Effects of CCC and moisture stress on sunflower. Experimental Agriculture, v. 9, p. 329-336, 1973. http://dx.doi.org/10.1017/S0014479700010127

MARINKOVIC, R. Path-coefficient analysis of some yield components of sunflower (Helianthus annuus L.), I. Euphytica, v. 60, p. 201-205, 1992.

MEIER, U. Growth stages of mono- and dicotyledonous plants. BBCH monograph, $2^{\text {nd }}$ ed. Berlin, Germany: German Federal Biological Research Centre for Agriculture and Forestry, 2001.

NAYLOR, R. E. L. Effects of the plant growth regulator chlormequat on plant form and yield of triticale. Annals of Applied Biology v. 114, p. 533-544, 1989. http://dx.doi.org/10.1111/j.1744-7348.1989.tb03369.x

PASSAM, H. C.; KOUTRI, A. C.; KARAPANOS, I. C. The effect of chlormequat chloride (CCC) application at the bolting stage on the flowering and seed production of lettuce plants previously treated with water or gibberellic acid (GA3). Scientia Horticulturae, v. 116, p. 117-121, 2008.

http://dx.doi.org/10.1016/j.scienta.2007.11.004

PRASAD, S.; SHUKLA, D. N. Effect of nitrogen and chlormequat chloride on the seed yield and oil content of mustard (Brassica juncea L. Czern \& Coss). Plant Growth Regulation, v. 10, p. 185-195, 1991. http://dx.doi.org/10.1007/BF00024409 
RADEMACHER, W. Growth retardants: effects on giberrelin biosynthesis and other metabolic pathways. Annual Review of Plant Physiology and Plant Molecular Biology, v. 51, p. 501-531, 2000. http://dx.doi.org/10.1146/annurev.arplant.51.1.501

RAJALA, A.; PELTONEN-SAINIO, P. Plant growth regulation effects on spring cereal root and shoot growth. Agronomy Journal v. 93, p. 936-943, 2001. http://dx.doi.org/10.2134/agronj2001.934936x

SPITZER, T.; MATUŠINSKÝ, P.; KLEMOVÁ, Z.; KAZDA, J. Management of sunflower stand height using growth regulators. Plant Soil and Environment, v. 57, p. 357-363, 2011

STACHECKI, S.; PRACZYK, T.; PRACZYK, K. Adjuvant effects on plant growth regulators in winter wheat. Journal of Plant Protection Research, v. 44, p. 365-371, 2004.

STEEL, R. G. D.; TORRIE, J. H. Principles and Procedures of Statistics: A Biometrical Approach, $2^{\text {nd }}$ ed. New York, USA: McGraw-Hill, 1980.

STOVER, E. W.; GREENE, D. W. Environmental effects on the performance of foliar applied plant growth regulators: a review focusing on tree fruits. HortTechnology, v. 15, p. 214-221., 2005.

TOLBERT, N. E. (2-Chloroethyl)-trimethylammonium chloride and related compounds as plant growth substances. I. Chemical structure and bioassay. Journal of Biological Chemistry, v. 235, p. 475-479, 1960.

TOYOTA, M.; SHIOTSU, F.; BIAN, J.; MOROKUMA, M.; KUSUTANI, A. Effects of reduction in plant height induced by chlormequat on radiation interception and radiation-use efficiency in wheat in Southwest Japan. Plant Production Science, v. 13, p. 67-73, 2009. http://dx.doi.org/10.1626/pps.13.67

WEISS, E. A. Oilseed crops, $\mathbf{2}^{\text {nd }}$ ed. London, UK: Blackwell Science, 2000.

YASIN, A. B.; SINGH, S. Correlation and path coefficient analyses in sunflower. Journal of Plant Breeding and Crop Science, v. 2, p. 129-133, 2010. 